\title{
Analisis Pemodelan Sistem Hibrid Proton Conducting Solid Oxide Fuel Cell (pSOFC)- Turbin Gas Mikro Pada Matlab-Simulink
}

\author{
Bayu Pranoto ${ }^{1}$, Chung-Jen Tseng ${ }^{2}$, ING Wardana ${ }^{3}$ \\ 1, 3Teknik Mesin Universitas Brawijaya Indonesia, JI. MT. Haryono, 167 - Malang 65145 \\ 2Department of Mechanical Engineering, National Central University, Taiwan \\ E-mail address: bayupranoto08@yahoo.com
}

\begin{abstract}
This study simulated Proton Conducting Solid Oxide Fuel Cell (pSOFC) - Micro Gas Turbine (MGT) hybrid system on three different configuration. The first configuration use bypass hot gas from combustor going to fuel heater without pass the turbine first. The second configuration use bypass hot gas out of turbine going to fuel heater. The third configuration is combined bypass out of combustor and also bypass out of turbine. The performance of these system are analyzed by using variation of operating pressure, fuel utilization (Uf), steam to carbon ratio $(S / C)$, and bypass valve. Moreover, the impact of different bypass position were also evaluated. The result shows that the efficiency of using a double bypass hot gas flow after combustor and turbine is about $67 \%$. This configuration became the best one among of another two configuration which proposed in this research. The utilization of heat by using a double bypass hot flow gas after turbine and combustor has proven more effective to increase the system efficiency. Means that it can reduce the heat losses of the system.
\end{abstract}

Keywords : Proton-Conducting Solid Oxide Fuel Cell (pSOFC), Micro Gas Turbine (MGT), MatlabSimulink, Hybrid configuration model

\section{PENDAHULUAN}

Saat ini beberapa penelitian tentang sistem hibrid SOFC-GT telah dan sedang gencar dilakukan. Hal ini banyak dilatarbelakangi bahwa fuel cell merupakan peralatan elektrokimia yang dapat mengubah dari energi kimia menjadi energi listrik secara langsung, dan juga memiliki efisiensi yang tinggi. Dikarenakan sistem SOFC memerlukan temperatur kerja yang tinggi yaitu sekitar $800^{\circ} \mathrm{C}-$ $1000^{\circ} \mathrm{C}$, membuatnya cocok untuk dikombinasikan dengan turbin gas. Demi untuk mendapatkan efisiensi sistem yang lebih baik, beberapa tahun terakhir para peneliti mengusulkan penelitian yang berkaitan dengan sistem hibrid SOFC-GT. Beberapa diantaranya ada yang menggunakan variasi bahan bahan bakar terbarukan seperti metanol sebagai sumber energi dari sistem hibrid SOFC-GT [4]. Ada pula yang memodifikasi konfigurasi sistem hibrid SOFC-GT, serta ada yang menggunakan variasi penambahan udara atau bahan bakar terhadap unjuk kerja sistem hibrid SOFC-GT [11]. Dari beberapa penelitian tersebut didapatkan hasil bahwa rata-rata efisiensi sistem meningkat hingga sekitar 60\%. Faktanya, diperlukan peningkatan efisiensi sistem hibrid yang lebih siknifikan hingga mencapai sekitar $70 \%$ untuk dapat bersaing dengan teknologi ramah lingkungan yang telah terlebih dahulu populer seperti misalnya teknologi pembangkit listrik tenaga angin.

Selain itu, usulan penggunaan temperatur kerja yang rendah dari fuel cell diperkirakan dapat membuatnya lebih bersaing di pasaran. Temperatur kerja yang lebih rendah memungkinkan fuel cell dibuat dengan material yang lebih murah. Sehingga dapat menurunkan biaya produksi serta dapat mempersingkat waktu yang dibutuhkan sistem saat start up dan shut down. Hal ini berarti bahwa sistem dapat bekerja dengan lebih fleksibel. Merujuk pada pemaparan tersebut, telah dikembangkan jenis fuel cell yang dapat bekerja pada temperatur yang lebih rendah dari SOFC. Fuel cell jenis ini disebut dengan proton conducting solid oxide fuel cell (pSOFC) atau disebut juga dengan intermediate temperature fuell cell. pSOFC bekerja pada temperatur sekitar $500^{\circ} \mathrm{C}-$ $750^{\circ} \mathrm{C}$ [1].

Dengan temperatur kerja yang relatif lebih rendah daripada SOFC, pSOFC sangat cocok dikombinasikan dengan turbin gas mikro. Hal ini merujuk pada kelemahan dari sistem turbin gas konvensional yang efisiensinya rendah dan masalah emisi $\mathrm{NO}_{x}$ yang ditimbulkan dari efek kerja combustor. pSOFC digunakan untuk menggantikan sebagian fungsi dari combustor sehingga turbin tetap mendapatkan panas yang cukup untuk menghasilkan kerja, dengan menggunakan pSOFC sebagai mesin konversi energi yang ramah lingkungan dan punya efisiensi yang tinggi. Disamping itu, peran combustor hanya sebagai pembakar sisa bahan bakar yang belum bereaksi di pSOFC untuk lebih mengoptimalkan panas yang dapat dihasilkan bahan bakar yang masuk ke dalam sistem. Sehingga diharapkan dapat meningkatkan effisiensi dari sistem hibrid proton conducting solid oxide fuel cell - turbin gas mikro.

Pada makalah ini menggunakan software matlab-simulink untuk memodelkan sistem hibrid pSOFC - turbin gas mikro, serta untuk mensimulasikan performa dari sistem hibrid yang diusulkan. Model dari sistem hibrid terdiri dari beberapa komponen diantaranya adalah kompresor, pompa bahan bakar, pemanas udara, pemanas bahan bakar, pSOFC, turbin gas mikro, combustor, dan reformer. Performa sistem hibrid diuji dengan 
menggunakan uji variasi tekanan sistem, fuel utilization, steam to carbon ratio, dan bypass ratio. Semua data hasil uji untuk tiap variasi dikumpulkan untuk selanjutnya dianalisa dan diambil kesimpulan. Makalah ini juga mencantumkan model konfigurasi yang digunakan dan persamaan-persamaan yang berkaitan dengan analisa hasil penelitian.

\section{METODE PENELITIAN Model Konfigurasi Sistem Hibrid}

Parameter yang digunakan pada makalah ini dalam menganalisa performa dari hibrid sistem adalah berdasarkan pada efisiensi sistem dan kerja yang dihasilkan pSOFC dan turbin gas mikro. Pemodelan sistem hibrid ditunjukkan pada Gambar 1. Bahan bakar (metanol) dialirkan masuk ke dalam sistem menggunakan pompa bahan bakar (fuel pump) untuk dialirkan menuju reformer. Sebelum mencapai reformer, bahan bakar dipanaskan terlebih dahulu menggunakan pemanas bahan bakar (fuel heater). Pemanasan bahan bakar dilakukan untuk melemahkan ikatan atom bahan bakar sehingga memudahkan proses produksi $\mathrm{H}_{2}$ (Hidrogen) dari $\mathrm{CH}_{3} \mathrm{OH}$ (metanol), dimana proses ini berlangsung di dalam reformer. Hidrogen yang dihasilkan oleh reformer selanjutnya dialirkan menuju sisi anoda dari pSOFC. Pada saat yang bersamaan, udara $\left(0,21 \mathrm{O}_{2}+\right.$ $0.79 \mathrm{~N}_{2}$ ) dialirkan masuk kedalam sistem menggunakan kompresor menuju pemanas udara (air heater) untuk dinaikkan temperaturnya. Selanjutnya udara yang telah dinaikkan temperaturnya dialirkan menuju sisi katoda dari pSOFC.

Di dalam $p S O F C$, terjadi reaksi termoelektrik sehingga pSOFC menghasilkan energi listrik sebagai yang menuju ke fuel heater. Panas yang dialirkan menuju ke fuel heater baik yang diambil dari aliran panas setelah combustor maupun dari aliran panas setelah turbin berperan sebagai sumber energi panas yang digunakan fuel heater untuk memanasi bahan bakar sebelum masuk reformer. Adapun panas yang keluar dari turbin menuju air heater berperan sebagai sumber panas yang digunakan air heater untuk meningkatkan temperatur udara yang masuk ke sisi katoda pSOFC. Sisa energi panas keluar reformer dibuang begitu saja ke lingkungan, sedangkan energi panas keluar air heater masih dapat digunakan untuk pemanas air atau dikonversikan ke bentuk energi yang lain sebelum dibuang ke lingkungan.

\section{Deskripsi Komponen Dalam Sistem}

Pada makalah ini menggunakan matlab-simulink untuk simulasi dan analisa performa sistem hibrid pSOFC-turbin gas mikro. Beberapa asumsi yang digunakan dalam penelitian ini diantaranya adalah:

1. Pressure losses di fuel cell, combustor, dan sistem pemipaan diabaikan

2. Campuran dari beberapa spesies kimia yang digunakan dalam penelitian ini diasumsikan dalam kondisi ideal

3. Aliran yang digunakan diasumsikan sebagai aliran steady state satu dimensi

4. Tidak ada kebocoran ke lingkungan untuk semua komponen dalam sistem

5. Pengaruh energi potensial diabaikan pada semua komponen

6. Perhitungan reaksi yang terjadi di reformer dan combustor hanya sampai pada tingkat reaksi umum, tidak sampai pada tingkat reaksi

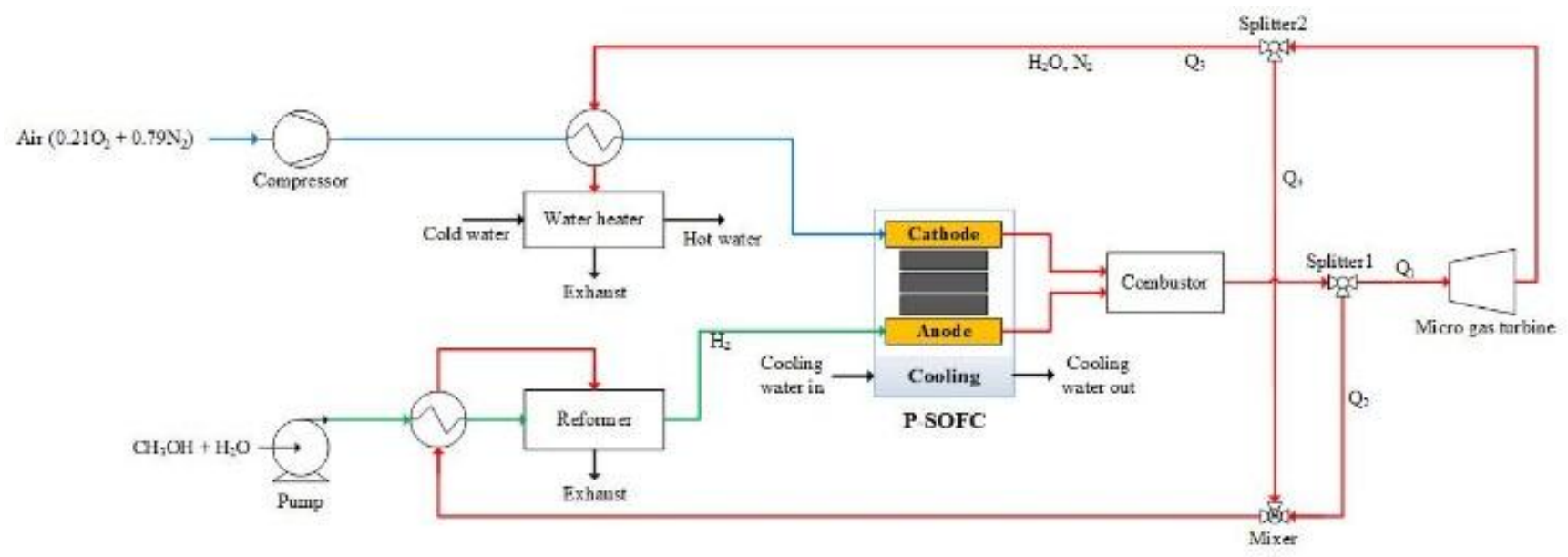

Gambar 1. Skema konfigurasi sistem hibrid pSOFC - turbin gas mikro

produk utama dan energi panas dalam jumlah tertentu. Sebagian besar energi panas yang merupakan produk keluaran sekunder dari pSOFC digunakan turbin untuk menghasilkan kerja. Sebagian kecil energi panas yang lain dialirkan langsung menuju ke fuel heater. Sisa energi panas dari turbin dialirkan menuju ke fuel heater dan air heater, dimana prosentase aliran yang lebih besar ada pada aliran elementer

\section{Model pSOFC}

Reaksi yang terjadi pada $p S O F C$ ditunjukkan pada persamaan (1) - (3) berikut ini:

$$
\begin{aligned}
& \mathrm{H}_{2} \longrightarrow 2 \mathrm{H}^{+}+2 \mathrm{e}^{-} \quad \text { (anode) } \\
& 2 \mathrm{H}^{+}+1 / 2 \mathrm{O}_{2}+2 \mathrm{e} \longrightarrow \mathrm{H}_{2} \mathrm{O} \text { (cathode) }
\end{aligned}
$$




$$
\mathrm{H}_{2}+1 / 2 \mathrm{O}_{2} \longrightarrow \mathrm{H}_{2}
$$

(overall reaction)

(3)

Untuk menghitung besarnya nilai voltase aktual dari $p S O F C$, dapat dengan menggunakan persamaan (4). Voltase aktual didefinisikan sebagai voltase reversibel dikurangi dengan total kehilangan voltase yang terdiri dari activation losses, ohmic losses, dan concentration losses.

\section{$V_{\text {actual }}=E-($ Activation Losses + Ohmic Losses + Concentration Losses)

Simbol E (dapat pula dituliskan sebagai $V_{\text {Nernst }}$ ) pada persamaan (4) dihitung dengan menggunakan persamaan (5)

$$
V_{\text {Nernst }}=\Delta E^{0}+R T \ln \frac{P H_{2}(a n) P O_{2}^{0.5}(c a)}{P H_{2} O(c a)}
$$

Dimana $\mathrm{pH}_{2}, \mathrm{pO}_{2}$ and $\mathrm{pH}_{2} \mathrm{O}$ masing-masing adalah tekanan parsial hidrogen, tekanan parsial oksigen, dan tekanan parsial air. Sedangkan subscripts 'an' and 'ca' masing-masing merepresentasikan anoda dan katoda. $R$ adalah universal gas constant $\left(8.3145 \mathrm{~J} \cdot \mathrm{mol}^{-1} \cdot \mathrm{K}^{-1}\right), T$ adalah temperatur absolut $(\mathrm{K})$ dan $F$ adalah konstanta Faraday $\left(96,485\right.$ Coulomb.mole $\left.{ }^{-1}\right)$, serta nilai untuk $\Delta E^{0}=1.2586-(0.000252 \times \mathrm{T})$.

Biasanya kondisi operasi ideal untuk fuel cell hampir tidak pernah terjadi. Hal ini karena pSOFC mengandung beberapa kehilangan energi yang selalu menyertai dalam setiap prosesnya. Kehilangan energi ini terdiri dari:

1. Activation losses (kehilangan energi akibat reaksi elektrokimia)

2. Ohmic losses (kehilangan energi akibat konduksi elektronik dan ionik)

3. Concentration losses (kehilangan energi akibat perpindahan massa)

Activation losses dapat dihitung dengan menggunakan persamaan (6), disebut juga sebagai persamaan Butler Volmer. Dimana $\alpha$ adalah activation barrier, $i$ and $i_{0}$ masing-masing adalah current density dan exchange current density. Selanjutnya saat kuat arusnya lemah, polarisasi atau kehilangan energi yang terjadi di cell didominasi oleh activation losses. Faktor lainnya, dengan activation polarization yang rendah akan meningkatkan temperatur, seberapa luas area dari elektroda, dan bagaimana aktivitas elektroda saat menggunakan katalis [2].

$$
\eta_{a c t}=A \cdot \ln \left(\frac{i}{i_{Q}}\right)=\frac{R \cdot T}{\alpha \cdot n_{B} \cdot F} \cdot \ln \left(\frac{i}{i_{Q}}\right), \quad A=\frac{R \cdot T}{\alpha \cdot n_{Q} F}
$$

pSOFC sangat dipengaruhi oleh ohmic losses, penurunan voltase yang terjadi karena tahanan di anoda, katoda, elektrolit, dan interkoneksi. Total ohmic loss $\left(\eta_{\text {ohm }}\right)$ dihitung dengan menggunakan persamaan (7).

$$
\eta_{O h m}=\frac{l}{\sigma A}
$$

Dimana I adalah panjang, $\mathrm{A}$ adalah cell active area $\left(\mathrm{m}^{2}\right), \sigma$ adalah konduktivitas proton $\left(\mathrm{A} \cdot \mathrm{m}^{-1}\right.$ or Coulomb. $\mathrm{s}^{-1} \cdot \mathrm{m}^{-1}$ ) yang dapat dihitung menggunakan persamaan (8).

$\sigma=0.009 . T-6.157$

Selanjutnya adalah kehilangan energi akibat concentration polarization $\left(\eta_{\text {conc }}\right)$. Concentration polarization dapat dikurangi dengan meningkatkan tekanan gas dan konsentrasi bahan bakar, menggunakan elektroda dengan area yang besar dan tipis. Rumus untuk menghitung concentration polarization ditunjukkan pada persamaan (9).

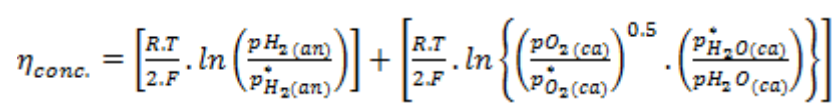

Dimana $\quad p_{H_{2}}^{*}, p_{O_{2}}^{*}, p_{H_{2} O}^{*}$ masing-masing merepresentasikan sebagai tekanan parsial hidrogen pada permukaan anoda-elektrolit, tekanan parsial oksigen pada permukaan katoda-elektrolit, dan tekanan parsial uap pada permukaan katodaelektrolit.

\section{Parameter Uji}

Untuk menganalisa performa dari sistem hibrid pSOFC - turbin gas mikro, pada penelitian ini menggunakan parameter uji yang terdiri dari efisiensi pSOFC, efisiensi sistem, dan efisiensi CHP (Combine Heat and Power). Efisiensi pSOFC yang ditunjukkan oleh persamaan (10) didefinisikan sebagai ratio dari energi listrik yang dihasilkan pSOFC terhadap kandungan energi kimia yang dimiliki bahan bakar pSOFC. Kandungan energi kimia bahan bakar disini merupakan hasil perkalian antara massa alir bahan bakar dengan nilai dari LHV (Low Heating Value) yang dimiliki bahan bakar.

$$
\eta_{\mathrm{pSOFC}}=\frac{P_{\mathrm{pSOFC}}}{\dot{\mathrm{m}}_{f} L H V_{f}}
$$

Merujuk pada persamaan (10), $P_{p S O F C}, \dot{m}_{f}$, dan $L H V_{f}$ masing-masing didefinisikan sebagai power dari $p S O F C$, massa alir bahan bakar, dan $L H V$. Disamping $P S O F C$ stack, kompresor dan turbin gas juga memainkan peranan penting dalam menentukan performa total dari sistem hibrid. Persamaan (11) dan (12) menunjukkan rumus untuk menghitung nilai dari efisiensi sistem dan efisiensi $\mathrm{CHP}$.

$$
\begin{aligned}
& \eta_{\text {system }}=\frac{P_{p S O F C}+P_{M G T}-P_{\text {Comp }}}{\dot{m}_{f} L H V_{f}} \\
& \eta_{C H P}=\frac{P_{p S O F C}+P_{M G T}+Q_{U s e f u I}-P_{C o m p}}{\dot{\mathrm{m}}_{f} L H V_{f}}
\end{aligned}
$$


Dimana, $P_{M G T}$ dan $P_{\text {comp }}$ masing-masing adalah power yang dihasilkan oleh turbin gas mikro dan power yang dikonsumsi kompresor untuk menghasilkan kerja selama proses berlangsung. Quseful adalah energi yang dapat dimanfaatkan misalnya untuk memanasi air atau diubah menjadi energi bermanfaat lainnya. Fuel utilization didefinisikan sebagai rasio banyaknya bahan bakar yang dikonsumsi terhadap banyaknya bahan bakar yang tersedia pada fuel cell, ditunjukkan pada persamaan (13).

$U_{f}=\frac{n_{H_{z}}^{r}}{n_{H_{2}}^{\text {tot }}}=\frac{\text { Consumed Fwel }}{\text { Available Fuel }}$

Steam to carbon ratio didefinisikan sebagai rasio massa aliran uap air terhadap massa alir bahan bakar, ditunjukan pada persamaan (14).

$$
S / C=\frac{\dot{m}_{H_{2} O}}{\dot{m}_{C_{g} O H}}
$$

\section{PEMBAHASAN}

Efek dari variasi tekanan operasi terhadap efisiensi sistem ditunjukkan oleh Gambar 2. Gambar 2 memperlihatkan bahwa antara tekanan operasi dan efisiensi sistem membunyai hubungan yang saling berkesesuaian, dimana meningkatnya tekanan operasi akan meningkatkan efisiensi sistem. Hubungan ini dijelaskan pada persamaan (11) yang memperlihatkan bahwa efisiensi tidak hanya dipengaruhi oleh kerja yang dihasilkan sistem, namun dipengaruhi pula oleh besarnya nilai energi masukan sistem yang didefinisikan sebagai massa alir bahan bakar masuk sistem. Dengan meningkatnya fluida kerja akan meningkatkan laju transfer panas pada turbin. Kenaikan transfer panas pada turbin inilah yang akan meningkatkan kerja turbin, sehingga kerja keseluruhan dari sistem hibrid juga meningkat. Kenaikan kerja sistem lebih tiggi dari kenaikan massa alir bahan bakar, sehingga efisiensi sistem meningkat.

Pada Gambar 3 menunjukkan adanya peningkatan efisiensi sistem yang signifikan dengan meningkatnya fuel utilization. Hal ini karena dengan meningkatnya fuel utilization berarti bahwa semakin banyak jumlah hidrogen yang tersedia di pSOFC diubah menjadi energi listrik. Dengan kata lain, semakin banyak hidrogen yang ikut berpartisipasi dalam reaksi elektrokimia untuk menghasilkan energi listrik. Semakin banyaknya hidrogen yang bereaksi di pSOFC menyebabkan jumlah bahan bakar yang belum bereaksi di pSOFC kemudian bereaksi di combustor semakin berkurang, sehingga temperatur masuk turbin menjadi lebih rendah. Rendahnya temperatur masuk turbin ini berdampak pada turunnya kerja turbin. Namun demikian penurunan kerja turbin tidak sebanding dengan kenaikan kerja pSOFC, sehingga efisiensi sistem secara keseluruhan tetap mengalami kenaikan dengan meningkatnya fuel utilization.

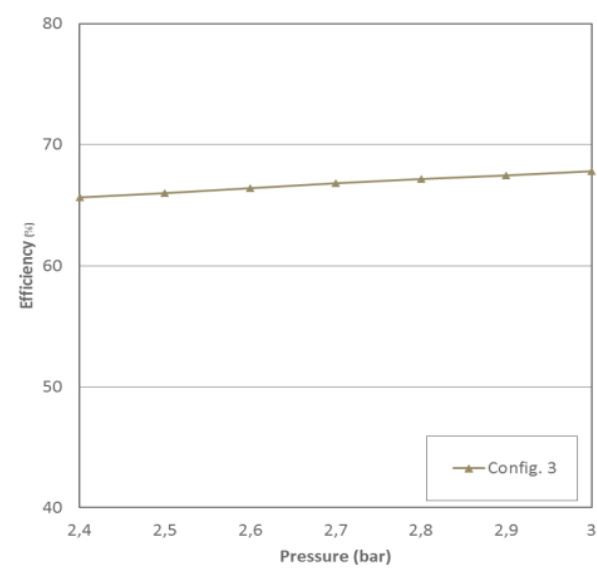

Gambar 2. Pengaruh variasi tekanan operasi sistem terhadap efisiensi sistem hibrid dengan

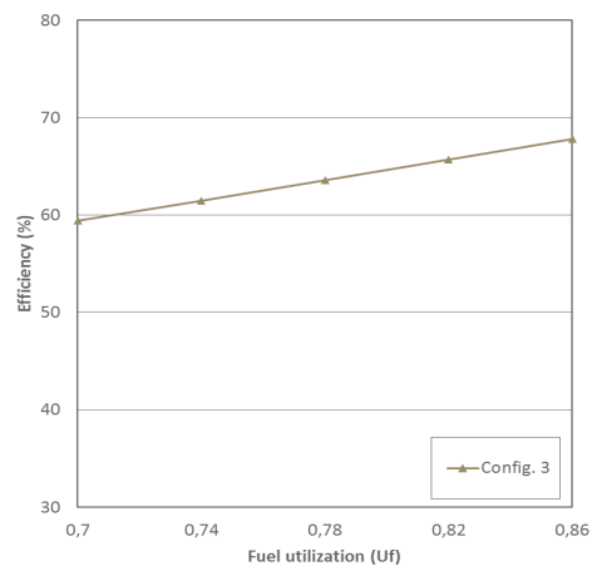

Gambar 3. Pengaruh variasi fuel utilization terhadap efisiensi sistem hibrid

Gambar 4 memperlihatkan efek dari variasi steam to carbon ratio terhadap efisiensi sistem. Kenaikan steam to carbon ratio dari $0.5-1$ menyebabkan kenaikan tekanan parsial hidrogen yang mana dapat meningkatkan jumlah produksi hidrogen di reformer. Meningkatnya produksi hidrogen berarti bahwa pSOFC dapat mengkonsumsi lebih banyak hidrogen sebagai bahan bakarnya untuk menghasilkan lebih banyak energi listrik. Semakin banyak energi listrik yang diproduksi berarti semakin meningkatkan efisiensi dari sistem hibrid secara keseluruhan. Selanjutnya kenaikan steam to carbon ratio $1-2$ meningkatkan efisiensi sistem namun peningkatannya sangat sedikit sekali. Hal ini dipengaruhi oleh nilai dari massa alir bahan bakar yang berubah untuk menjaga nilai voltasenya konstan. Meskipun, menggunakan nilai Fuel STO dan Air yang konstan selama melakukan variasi steam to carbon ratio yang mana masing-masing besarnya 1,2 dan 3. 


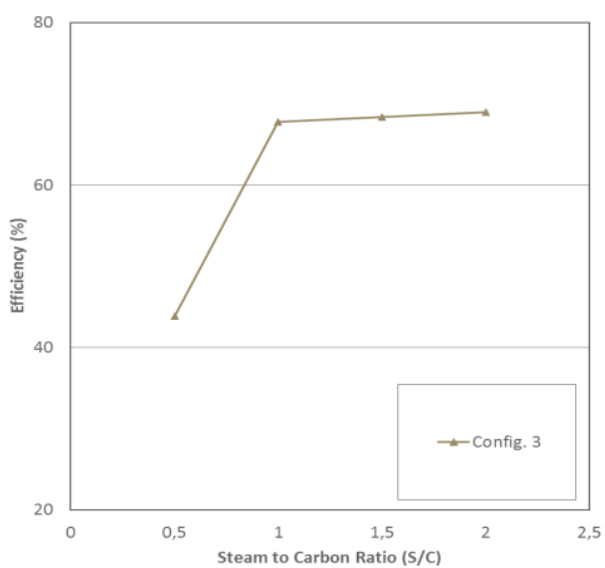

Gambar 4. Pengaruh variasi steam to carbon ratio terhadap efisiensi sistem hibrid

Gambar 5 menjelaskan hubungan antara pengaruh dari bypass ratio terhadap efisiensi sistem. Kenaikan bypass ratio menyebabkan kenaikan jumlah produksi hidrogen yang berdampak pula pada meningkatnya energi listrik yang dihasilkan oleh pSOFC. Hal ini dipengaruhi oleh kenaikan temperatur pada fuel heater dan reformer yang memicu semakin mudahnya reaksi pembentukan hidrogen dari metanol. Meningkatnya jumlah hidrogen yang diproduksi reformer meningkatkan energi listrik yang dihasilkan pSOFC dan juga energi listrik yang dihasilkan oleh turbin gas mikro. Hal ini berdampak pada meningkatnya efisiensi sistem hibrid secara keseluruhan dengan meningkatnya nilai dari bypass ratio.

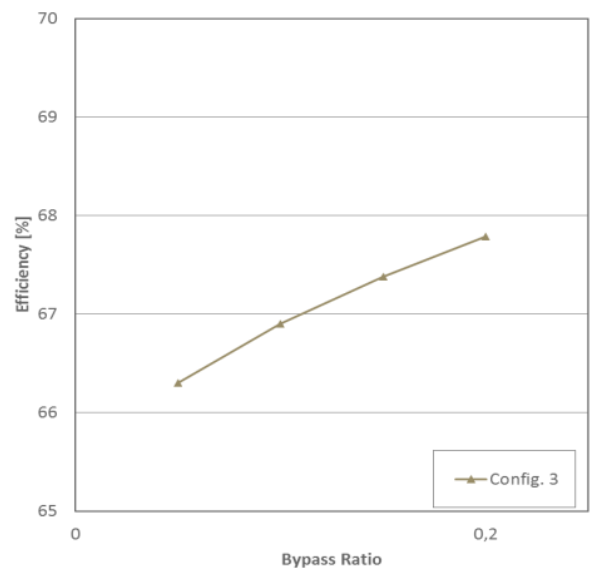

Gambar 5. Pengaruh variasi bypass ratio terhadap efisiensi sistem hibrid

\section{KESIMPULAN}

Merujuk pada analisa hasil yang telah dilakukan pada penelitian ini, disimpulkan bahwa:

1. Penggunaan katup pemotong aliran panas rangkap pada sistem hibrid pSOFC - turbin gas mikro dapat meningkatkan efisiensi dengan lebih baik.

2. Menggunakan katup pemotong aliran panas rangkap menjanjikan untuk performa sistem hibrid yang lebih baik dan juga berkompeten untuk diaplikasikan pada penggunaan beban pemakaian listrik yang besar hingga skala ribuan megawatt.

3. Dengan metode katup rangkap ini lebih memudahkan dalam perawatan dan mengurangi resiko terjadinya overheating atau panas berlebih pada sistem.

4. Untuk penelitian selanjutnya dapat dilakukan penambahan variasi nilai tekanan yang jauh lebih tinggi hingga tekanan sekitar 20 bar, sehingga nantinya dapat dioperasikan menjadi trigeneration hibrid sistem dimana memadukan antara pSOFC, turbin gas, dan turbin uap.

\section{DAFTAR PUSTAKA}

[1] Arpornwichanop, Y. Patcharavorachat and S. Assabumrungrat, "Analysis of a proton conducting SOFC with direct internal reforming", Chemical Engineering Science, Vol. 65, pp. 581-589, 2010.

[2] Angrist, W. Stanley, Direct Energy Conversion, Boston, Allyn and Bacon, 1965.

[3] J. Larminie, A. Dicks. Fuel cell systems explained. New York: John Wiley and Sons, Inc.; 2000.

[4] J. Palsson, A. Selimovic, L. Sjunnesson. "Combined solid oxide fuel cell and gas turbine systems for efficient power and heat generation", Journal of Power Sources, Vol.. 86, pp. 442-8, 2000.

[5] S.H. Chan, H.K. Ho, Y. Tian. "Multi-level modeling of SOFC-gas turbine hybrid system", International Journal of Hydrogen Energy, Vol. 28, pp. 889900, 2003.

[6] P. Costamagna, L. Magistri, A.F. Massardo. "Design and part-load performance of a hybrid system based on a solid oxide fuel cell reactor and a micro gas turbine", Journal of Power Sources, Vol. 96, pp. 352-368, 2001.

[7] S. Samuelsen, Turbo fuel cell report: Fuel Cell/Gas Turbine Hybrid Systems, National Fuel Cell Research Center, University of California, Irvine, CA, Feb, 2004.

[8] T.W. Song, J.L. Sohn, J.H. Kim, T.S. Kim, S.T. Ro, K. Suzuki. "Performance analysis of a tubular solid oxide fuel cell/gas turbine hybrid power system based on a quasi-two dimensional model", Journal of Power Sources, Vol. 142, pp. 30-42, 2005.

[9] S.H. Chan, H.K. Ho, Y. Tian. "Modeling of simple hybrid solid oxide fuel cell and gas turbine power plant", Journal of Power Sources, Vol. 109, pp. 111-20, 2002.

[10] S.H. Chan, H.K. Ho, Y. Tian. "Modeling of partload operation of solid oxide fuel cell-gas turbine hybrid power plant", Journal of Power Sources, Vol. 114, pp. 213-27, 2003.

[11]J. S. Yang, Jeong L. Sohn, Sung Tack Ro. "Performance characteristics of part-load operations of a solid oxide fuel cell/gas turbine hybrid system using air-bypass valves", Journal of Power Sources, Vol. 175, pp. 296-302, 2008.

[12] F. Calise, M. Dentice d'Accadia, A. Palombo, L. Vanoli. "Simulation and exergy analysis of a hybrid Solid Oxide Fuel Cell (SOFC)-Gas Turbine 
System", Journal of Energy, Vol. 31, pp. 32783299, 2006

[13] P. I. Cowin, C. T. G. Petit, R. Lan, J. T. S Irvine, and S. Tao, "Recent Progress in the Development of Anode Materials for Solid Oxide Fuel Cells", Advanced Energy Materials, Vol 1, pp. 314-332, 2011.
[14]P. Ranran, W. Yan, Y. Lizhai and M. Zhongqiang, "Electrochemical properties of intermediatetemperature SOFCs based on proton conducting Sm-doped $\mathrm{BaCeO}_{3}$ electrolyte thin film", Solid State lonics, Vol 177, pp. 389-393, 2006.

[15]EG\&G Technical Services, Inc, Fuel Cell Handbook, U.S. Department of Energy, National .Energy Technology Laboratory, West Virginia, Nov, 2004. 